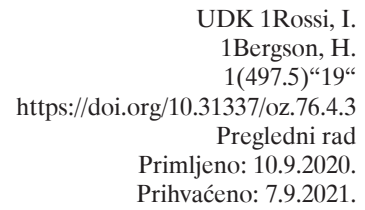

\title{
Hrvatska filozofkinja Ivana Rossi o filozofiji Henrija Bergsona
}

\author{
Ivana Skuhala Karasman*
}

\begin{abstract}
Sažetak
Ivana Rossi (1892.-1963.) prva je Hrvatica koja je 1916. godine na Zagrebačkom sveučilištu doktorirala filozofiju tezom Osnovne misli filozofije Henri Bergsona. Profesionalno je radila kao gimnazijska profesorica. Objavila je dva rada: članak Nekoliko misli Henri Bergsona o estetici (1929.) i prijevod s engleskoga Peter Pan u perivoju Kensington (1922.). Ovdje donosim gotovo nepoznatu biografiju Ivane Rossi, sažetak njezine disertacije i pregled recepcije Bergsonove filozofije u nas.
\end{abstract}

Ključne riječi: Ivana Rossi; Henri Bergson; filozofkinja; disertacija; recepcija Bergsonove filozofije; psihologija; metafizika

\section{Uvod}

O filozofkinji Ivani Rossi, rođenoj 1892. u Glini i umrloj 1963. u Zagrebu, nema objavljenih radova, što čudi s obzirom na to da je ona bila prva Hrvatica koja je promovirana u doktoricu filozofije na Zagrebačkom sveučilištu. To je bilo 1916. godine nakon obrane disertacije pod naslovom Osnovne misli Henri Bergona na Mudroslovnom (Filozofskom) fakultetu u Zagrebu. ${ }^{1}$ Naime, na zagrebačkom Filozofskom fakultetu ženama je bilo dopušteno studiranje tek od 1901.

* Dr. sc. Ivana Skuhala Karasman, viša znanstvena suradnica, Institut za filozofiju. Adresa: Ulica grada Vukovara 54, 10000 Zagreb, Hrvatska. ORCID iD: https://orcid.org/0000-0001-77695259. E-adresa: ivana@ifzg.hr

Ovaj je članak rezultat istraživanja na projektu Hrvatske filozofkinje u europskom kontekstu, koji pod oznakom HRZZ UIP-2017-05-1763 financira Hrvatska zaklada za znanost.

1 Ivanu Rossi spomenula je Ljiljana Filipović (2016, 69, bilj. 83) u svojoj knjizi Krug krivaca. Prema mojim saznanjima to je prvo pisano spominjanje te hrvatske filozofkinje. Ipak, netočan je podatak koji navodi Filipović da je Rossi prva Hrvatica koja je 1916. godine doktorirala filozofiju. Prije nje filozofiju je doktorirala njezina rođakinja Elza Kučera u Zürichu 1909., a Austrijanka hrvatskoga podrijetla Helene Druskowitz doktorirala je filozofiju 1878. također u Zürichu. Rossi je prva Hrvatica koja je doktorirala filozofiju na Filozofskom fakultetu u Zagrebu (Filipović, 2016, 69). Ivana Rossi bila je i temom triju referata Željke Metesi Deronjić: 2016. godine Doktorska disertacija Ivane Rossi na konferenciji Filozofkinje u Hrvatskoj; 2017. godine Profesorska djelatnost Ivane Rossi, prve doktorice filozofije u Hrvatskoj na konferenciji Hrvatska filozofija i znanost: jučer, 
godine. Usporedbe radi, ženama je bilo dopušteno studiranje kao redovnih studentica na Sveučilištu u Zürichu već od 1867. godine. »Prve redovite studentice koje su akademske godine 1901/1902. upisale studij na Mudroslovnom fakultetu bile su Milica pl. Bogdanovićeva iz Vrginmosta kraj Topuskog, studentica povijesti i geografije, te Milka Maravić iz Zagreba i Vjera Tkalčić iz Zagreba, studentice prirodoslovlja « (Luetić, 2001, 11). Jedna od prvih žena koje su studirale na Filozofskom fakultetu u Zagrebu bila je poznata profesorica, književnica i prevoditeljica Camilla Lucerna (1868.-1960.), koja je bila »među prvim ženama kojima dozvoliše da prekorače prag hrvatskog sveučilišta « (Kučera, 1938, 4). Prva žena koja je 1907. godine na toj ustanovi doktorirala tezom Julijan Apostat prema hršćanstvu bila je Milica Bogdanović (1882.-1973.). Druga doktorica znanosti na Filozofskom fakultetu u Zagrebu bila je Josipa Steinkuš, koja je doktorirala 1912. godine tezom Negacija u pitanjima kod Homera. U popisu prvih žena doktorica na Filozofskom fakultetu Luetić spominje i Ivanu Rossi (Luetić, 2002, 197).

Disertacija Ivane Rossi Osnovne misli Henri Bergsona pohranjena je u Arhivu knjižnice Filozofskoga fakulteta Sveučilišta u Zagrebu. Rossi nikad nije objavila svoju disertaciju, a jedini je njezin objavljen filozofski tekst Nekoliko misli Henri Bergsona o estetici ima svega jednu stranicu (Rossi, 1929). Svoj čitav radni vijek provela je radeći kao samozatajna gimnazijska profesorica. U drugom poglavlju ovoga članka donosim sadržaj disertacije Ivane Rossi, koja je dobar primjer informativnoga teksta za upoznavanje filozofske misli Henrija Bergsona (1859.-1941.), u kojoj Rossi obrađuje dva temeljna pojma Bergsonove filozofije: instinkt $\mathrm{i}$ intuiciju.

\section{Biografija Ivane Rossi}

Ivana Rossi rođena je 5. svibnja 1892. godine u Glini. Nedugo nakon rođenja krštena je te je tom prilikom dobila ime Maria Antonia. Međutim, iz njezine korespondencije s rođakinjom, također hrvatskom filozofkinjom, psihologinjom i bibliotekarkom, Elzom Kučera² saznajemo da su ju svi jednostavno zvali Seka. Ivana Rossi potjecala je iz dobrostojeće obitelji. Njezina majka Melanija pl. Bugarin potjecala je iz ugledne austro-ugarske plemićke obitelji ruskoga podrijetla, Bugarin od Sokolplanine. ${ }^{3}$ Otac Franjo Rossi bio je sudac i umro je kada je Ivana imala svega devet godina. Vjerojatno je tada s majkom preselila u Zagreb, gdje

danas, sutra 3; 2019. godine Who is Ivana Rossi - the Little-known Translator of the first Peter Pan Edition in Croatia? na konferenciji Beyond the Canon (Of Children's Literature).

2 Elza Kučera (1883.-1972.), kći hrvatskoga astronoma i matematičara Otona Kučere (1857.1931.). Doktorirala je filozofiju na Sveučilištu u Zürichu 1909. godine tezom Die Erkenntnistheorie von Thomas Brown: Eine historische Studie ("Spoznajna teorija Thomasa Browna: Povijesna studija"). Time je postala prva Hrvatica rođena u Hrvatskoj koja je stekla doktorat iz filozofije.

3 Ivanin ujak, Melanijin brat, bio je Emil pl. Bugarin od Sokolplanine, austrougarski potpukovnik i odlikovani junak Prvoga svjetskoga rata koji je poginuo 1914. u borbi u Galiciji, što su tada prenijele sve novine u zalazećem Carstvu. 
je od 1902. do 1910. godine polazila glasoviti Ženski licej, koji je otvoren 1892. godine:

»Prema statutu, Licej je trajao osam godina i dijelio se u dvije četverogodišnje zaokružene cjeline. U višim razredima Liceja obuka se dijelila u tri smjera: pedagoški, latinski i opći. Smjerovi su se razlikovali jedino po odabiru relativno obligatnih predmeta: pedagogije, latinskog ili engleskog jezika. Učenice pedagoškog smjera mogle su polagati stručni ispit za učiteljice, djevojke koje su odabrale engleski stjecale su opću naobrazbu potrebnu za rad kao guvernante, a one koje su odabrale latinski pripremale su se za sveučilišno obrazovanje «(Ograjšek Gorenjak, 2006, 158).

Zasigurno je Rossi u Liceju dobila dobru naobrazbu, koja joj je omogućila da svoje obrazovanje nastavi na sveučilištu. Nakon mature studirala je od 1910. do 1914. godine na Mudroslovnom (Filozofskom) fakultetu Sveučilišta u Zagrebu filozofiju kao glavnu i fiziku kao sporednu struku. Na Filozofskom fakultetu u Zagrebu Ivana Rossi je i doktorirala 3. srpnja 1916. godine s tezom Osnovne misli filozofije Henri Bergsona.

Radila je kao gimnazijska profesorica na Kraljevskoj ženskoj realnoj gimnaziji (HR-DAZG-114), koja je bila smještena na Katarinskom trgu br. 5 u Zagrebu, a jedno kraće vrijeme bila je i ravnateljica spomenute gimnazije. U toj školi radila je prvo od 21. listopada 1916. godine kao pomoćna učiteljica, zatim od 4. veljače 1917. godine kao namjesna učiteljica, a 29. rujna 1920. godine imenovana je pravom učiteljicom. Naslov profesora dodijeljen joj je 13. srpnja 1922. godine. Od 19. ožujaka 1946. godine radila je u Partizanskoj realnoj gimnaziji, ${ }^{4}$ koja je godinu dana kasnije promijenila ime u Gimnazija maršala Tita (HR-DAZG-108) i koja je bila smještena u Gundulićevoj ulici br. 30. No nakon dvije godine premještena je u III. mušku realnu gimnaziju u Zagrebu (HR-DAZG-111), koja se je nalazila u Kušlanovoj ulici br. 23. Predavala je specijalnu filozofiju, ${ }^{5}$ matematiku i fiziku.

Ivana Rossi govorila je više stranih jezika. Izvrsno je vladala njemačkim, engleskim i francuskim jezikom, a razumjela je češki i ruski. S engleskoga na hrvatski jezik prevela je djelo Jamesa Barrieje Peter Pan u perivoju Kensington (Barrie, 1922), što je prvi prijevod knjige o popularnom dječjem junaku Peteru Panu na naš jezik. Upravo je ta knjiga 1936. godine bila izložena na Izložbi knjiga ženskih pisaca u Dubrovniku, koju je organizirala Elza Kučera.

Elza Kučera, prva Hrvatica koja je promovirana u doktoricu filozofije na Sveučilištu u Zürichu, i Ivana Rossi, prva Hrvatica koja je promovirana u doktoricu filozofije na Sveučilištu u Zagrebu, bile su rođakinje i sačuvana nam je njihova

4 "Partizanske gimnazije" bile su škole za učenike koji su prekinuli školovanje tijekom rata, neki zbog aktivnoga sudjelovanja u Narodnooslobodilačkoj borbi, a neki zbog boravka u logorima i zbjegovima. U tim gimnazijama učenici su mogli ubrzanim školovanjem nadoknaditi izgubljene godine. Postojale su tri takve gimnazije na području Hrvatske: Gimnazija Maršala Tita u Zagrebu, Gimnazija Vladimira Nazora u Hvaru i Gimnazija Ive Lole Ribara u Osijeku. One su prestale s ubrzanim školovanjem na kraju školske godine 1947./48. (Marčeta, 2011, 22).

5 Specijalna filozofija omogućava učenicima uvid u posebna područja filozofije koja se koriste za produbljivanje znanja o humanističkim i društvenim temama. Zanimljiva je i u okviru prirodnih znanosti. 
skromna korespondencija. Ivana Rossi poslala je dvanaest pisama Elzi Kučeri, od kojih je prvo datirano 8. kolovoza 1918. godine (HR-NSK-R 4771b). Pisma Elze Kučere Ivani Rossi nisu sačuvana. Premda iz same korespondencije, u kojoj su sadržana spominjanja pretežno efemernih događaja, ne možemo mnogo saznati o njihovim filozofskim interesima i možebitnim razgovorima, razvidno je da su obje, usprkos svojim profesijama koje se nisu izravno ticale njihova obrazovanja, sačuvale živi interes za filozofske teme. Iz biografije Elze Kučera saznajemo da je ona zajedno s Ivanom Rossi od 1933. do 1936. godine sudjelovala u izvođenju vježbi na Katedri za eksperimentalnu psihologiju Sveučilišta u Zagrebu. Cilj vježbi bio je izraditi metodologiju za istraživanje doživljaja ljepote.

Rossi je jednako kao i Kučera osjećala veliko divljenje prema svojoj profesorici iz Liceja Camilli Lucerni, prevoditeljici, filologinji, dramatičarki i pedagoginji, kojoj je često slala pozdrave preko Elze Kučera.

Ivana Rossi umrla je u Zagrebu 12. srpnja 1963. godine i pokopana je na Mirogoju.

\section{Disertacija Ivane Rossi}

Disertaciju pod naslovom Osnovne misli filozofije Henri Bergsona Ivana Rossi obranila je na Mudroslovnom fakultetu Kraljevskoga sveučilišta Franje Josipa u Zagrebu 1916. godine. Kao što je već više puta spomenuto, ona je prva Hrvatica koja je promovirana u doktoricu filozofije na zagrebačkom sveučilištu, premda nije prva Hrvatica koja je promovirana u doktoricu filozofije: prije nje su doktorirale Elza Kučera i Helene Druskowitz, obje u Zürichu. U komisiji za obranu disertacije Ivane Rossi bili su filozofi Gjuro Arnold (1853.-1941.) i Albert Bazala (1877.-1947.), dvojica tada najuglednijih hrvatskih filozofa. Disertacija ima 108 stranica i podijeljena je na sljedeća poglavlja: I. Uvod; II. Principi Bergsonove metode; III. Psihologija (A. Karakteristika psihičkih doživljaja; B. Intenzitet duševnih stanja; C. Trajanje; D. Problem slobode volje; E. Materija i pamćenje); IV. Metafizika (A. Uvod; B. Životni zamah: Intelekt i instinkt; C. Bergsonovo stajalište prema dosadašnjim sistemima); V. Zaključak.

U uvodu Rossi nudi pregled glavnih filozofskih struja koje su bile aktualne kad se Bergson počeo intenzivno baviti filozofijom. Rossi započinje s navođenjem glavne karakteristike francuske filozofije 18. i 19. stoljeća, koja stremi k tomu da se pomoću upoznavanja svijeta dosegne pravednije ljudsko društvo, sažeto u formuli par la vérité, pour la justice ("istinom za pravednost"). ${ }^{6}$ Filozofija u Francuskoj prema Rossi obilježena je dvjema bitnim karakteristikama koje proizlaze iz filozofske misli Augusta Comtea (1798.-1857.). Prva je karakteristika vezanost filozofije uz socijalni život, što je kod Comtea dovelo do uspostave socijalne fizike, tj. sociologije. Druga je karakteristika težnja za sigurnim i izvjesnim znanjem, koja se kod Comtea manifestira pozitivistički utemeljenom filozofijom.

6 Fraza par la vérité, pour la justice nalazi se na kraju članka La philosophie en France depuis 1867 Émila Boutrouxa (1908, 716). 
Ta tendencija proširuje se općenito na suvremenu filozofiju, koja se pokušava utemeljiti na iskustvu i ostaje vezana uz pojedinačne znanosti. Jedna od bitnih osoba koje su utjecale na razvoj filozofije u Francuskoj toga vremena bio je Jules Lachelier (1832.-1918.). On je osnivač neospiritualizma te je uveo kritičku filozofiju u Francusku. Osnovni mu je cilj bio ovjekovječiti Kantovu filozofiju. Ostavio je bitan utjecaj na svoje studente i sve koji su ga slušali, oslobađajući im umove i otvarajući nove perspektive (Ballard, 1960, I). Toj školi pripadaju Étienne Émile Marie Boutroux (1845.-1921.), Arthur Hannequin (1856.-1905.) i Henri Bergson. Kada je Bergson ušao u filozofiju bile su dominantne sljedeće misli: 1. polazi se od Kantova kriticizma; 2. filozofi koji joj pripadaju žele pokazati nedostatke mehanicističkoga shvaćanja svijeta i determinizma te žele zasnovati filozofiju slobode. Bergson u svojoj filozofiji nije krenuo utabanim putem, nego je krenuo iz početka. Smatrao je da treba sumnjati u sva znanja koja su postojala prije njega i da treba krenuti od neposredno danoga. Prvi su njegovi radovi psihološki. Smatrao je, naime, da su psihološka istraživanja podloga metafizičkim istraživanjima. U svojem glavnom djelu L'évolution créatice ("Stvaralačka evolucija”) iz 1907. godine opisuje svoju evolucijsku i intuitivnu filozofiju. On želi izgraditi modernu fiziku na temelju poznavanja psihologije, fiziologije, patologije i biologije. Takva su filozofska stajališta u vezi s filozofijom Williama Jamesa (1842.-1910.) i Rudolfa Euckena (1846.-1926.).

Disertacija obrađuje načela Bergsonove metode. U drugoj polovici 19. stoljeća filozofija je sve više padala u drugi plan, a važnim je smatrano samo prirodoznanstveno istraživanje. No, javila se je potreba da se znanost zbliži sa životom, da se pronađe prijelaz i veza između filozofije i znanstvenoga shvaćanja svijeta. I Bergson se je bavio problemom odnosa filozofije i znanosti. Razlika između filozofije i znanosti, prema Bergsonu, leži u metodama kojima se one koriste. Za njega je metafizička metoda radikalno različita od znanstvene. Znanost se koristi analizom, a metafizika se koristi intuicijom i ona je usmjerena na cjelinu, za razliku od znanstvene metode, koja se bavi pojedinostima. Načelo intuicije Bergson je iznio u svojem djelu Introduction à la métaphysique. Načela je podijelio u devet točaka:

»1. Zdrav razum imade pravo držeći, da postoji izvanjski svijet onakav, kakav se očituje našem neposrednom opažaju. Ni filozofski realizam ni idealizam nisu opravdani. Postoji dakle izvanjska realnost, koja je ipak našem duhu neposredno dana. [...] 2. Skup svih slika jest realnost, a glavno svojstvo njezino je gibanje. Nema gotovih stvari ni nepromjenjivih stanja, sve je u nastajanju i mijeni. Mirovanje je uvijek samo prividno, relativno. [...] 3. U običnom je životu najvažnija funkcija intelekta predočavanje pojedinih stvari i stalnih stanja; intelekt tražeći čvrsta uporišta radi predodžbama i idejama, pa tim supstituira diskontinuitet i mirovanje kontinuiranoj gibivoj realnosti. [...] 4. Poteškoće, koje se metafizici nameću, antinomije, koje ona izaziva, nepomirljive suprotnosti izmedju raznih sistema imadu svoj izvor velikim dijelom u pogješnom primjenjivanju praktičkog načina spoznavanja na neinteresovano metafizičko spoznavanje. [...] 5. Od iste su nemogućnosti polazili i skepticizam i idealizam i kriticizam, uopće sve doktri- 
ne, koje tvrde, da je spoznaja o apsolutnome nemoguća. [...] 6. Zapravo može i mora naša spoznaja ići obrnutim putem. Ona može stvarati gibivu zazbiljnost, poprimiti njezine smjerove, koji se neprestano mijenjaju, obuhvatiti ih intelektualnim proživljavanjem, koje zovemo intuicijom. [...] 7. Taj se obrnuti način mišljenja nije do sada razvio u svjesnu metodu, no produljena će povijest ljudskoga mišljenja pokazati, da njemu imademo zahvaliti sve najdublje misli i u metafizici i u ostalim znanostima. [...] Filozofska bi se metoda — drži Bergson — morala izgraditi po analogiji infinitezimalne metode matematike. [...] 8. Bergson dalje drži, da je razlog tomu što je filozofija izgubila s vida svoju zadaću da promatra gibiv kontinuitet činjenica što činjenica jednaput stečena intuitivna spoznaja mora naći modus izražaja, modus, koji je primjeren našem običnom mišljenju. [...] 9. Antikna filozofija bila je toga uvjerenja, da ne postoje dva razna načina spoznaje stvari, te da razne znanosti imadu svoj korijen u metafizici« (Rossi, 1916, 9-13).

Disertacija je usredotočena na dva momenta: na psihološki i na metafizički dio Bergsonove filozofije.

\subsection{Treći dio disertacije: psihologija}

Ivana Rossi započinje analizom karakteristika psihičkih doživljaja, točnije njihovom metodom. Na početku poglavlja ovako određuje psihički doživljaj: »U realnosti pojava nalazi se nesumnjivo bar jedna [karakteristika psihičkih doživljaja], koju shvaćamo neposredno intuitivno, a to je naš psihički život « (Rossi, 1916, 18). Karakteristične su crte duševnoga života mnogolikost, kvaliteta, kontinuitet razvitka i jedinstvo smjera. Psihički život može se shvatiti samo intuicijom. Intuicija se mora služiti pojmovima. Analiza "ja", koje je dano intuicijom, pretpostavlja da se "ja" nalazi isključivo u intelektualnoj sferi, dočim, prema njezinu razumijevanju Bergsona, ono se nalazi među osjetima, čuvstvima i predodžbama. Time na mjesto "ja” stavlja niz elemenata. Bergson smatra da je sljedeće pitanje najvažnije u psihologiji: Jesu li elementi dijelovi duševnoga života, odnosno jesu li realni ili su samo znanstvene apstrakcije? On smatra da elementi nisu realni, oni su samo fragmenti simbola, a ne samoga objekta. Nemoguće je od tih fragmenata rekonstruirati čitav duševni život, iako su filozofi to pokušavali. Bergson smatra da je psihologija išla krivim putem koji ju ne vodi k cilju. Njegova nova metoda zove se empirička. Bergson navodi kako pravi empirizam pokušava privući original k sebi koliko god je to moguće, zatim teži istražiti njegov život i osjetiti kakva mu »duša bije «. Takav empirizam prava je metafizika. Pomoću takvoga empirizma dolazi se do spoznaje da je ličnost jedinstvo i mnoštvo. Pitajući se o naravi jedinstva i mnoštva Bergson počinje istraživati pojam intenziteta. On često naglašava da u filozofiji nedostaje govornoga istraživanja i intelektualnoga spoznavanja, kako to Rossi objašnjava:

»Govor je nastao iz potreba praktičnoga života, a filozofska spoznaja nema ništa zajedničkoga s potrebama običnog djelovanja. Bergsonu doduše nije čista spoznaja sasvim odijeljena od djelovanja, no ona ima da vodi k slobodnom djelovanju, a ne na mehaničkom kakovo se zbiva u običnom životu koji smjera uvijek na neki interes. Bergsonu nije čisto teoretsko spoznavanje najviši ideal, no 
ipak njegovo mišljenje o neinteresovanoj spoznaji sjeća na Platonovo shvaćanje Erosa, kao čežnje za čistim gledanjem ideja; tako da konačno ipak upućuje na spoznaju, koja ne pokazuje put k djelovanju« (Rossi, 1916, 21).

Slijedi poglavlje koje se bavi intenzitetom duševnih stanja. Smatra se da se psihička stanja, čuvstva i težnje mogu uvećati ili pak umanjiti. Prema Bergsonu takav se način izražavanja zasniva na krivom primjenjivanju pojma veličine. Postavlja se pitanje odnosa između intenzivnih i ekstenzivnih veličina. Postoje tri mišljenja o mjerenju intenziteta: 1 . veličinu intenziteta duševnoga stanja moguće je mjeriti prema jačini podražaja; 2. moguće ju je mjeriti usporedbom sadašnjega stanja s prijašnjim; 3. kinetička i mehanička teorija smatra da je kvaliteta razlika kvantiteta gibanja i ona su uzrok svim promjenama. Bergson želi odrediti u čemu se nalazi percepcija osjetilnoga intenziteta. On smatra da »u onoj mjeri u kojoj nam se čini, da neko dano naprezanje raste na jačini zapravo raste broj simpatetično kontrahiranih mišića, i da se prividna percepcija većeg intenziteta dade svesti na percepciju veće površine tijela koja je podražena« (Rossi, 1916, 25). Svijet o rastu mišićnoga naprezanja može se svesti na dvostruku percepciju: 1. na veći broj perifernih osjetila; 2 . na kvalitativne razlike koje se u nekima događaju. Bergson se pita »kako je moguće od odnošaja izmedju osjeta i njegovog minimalnog prirasta doći do jednadžbe, koja spaja 'kvantitet osjeta' s podražajem koji mu odgovara « (Rossi, 1916, 26). Psihologija prije Bergsona smatrala je da se u osjetu mora razlikovati kvaliteta i kvantiteta: »Prema Bergsonovu shvaćanju je kvalitet nekoga osjeta svojstvo, kojim se on razlikuje od osjeta raznih imena, a intenzitet je kvalitativna razlika izmedju osjeta istog imena. [...] Za Bergsona postoji samo razlika kvaliteta« (Rossi, 1916, 29).

U poglavlju o trajanju Rossi započinje s Bergsonovom tvrdnjom da »broj je jednostavna intuicija, mnogolikost ili jedinica, koje su međusobno potpuno jednake« (Rossi, 1916, 30). Međutim, jedince se ipak po nečemu moraju razlikovati, a ono po čemu se razlikuju jest prostor. Bergson ovako definira prostor: »Prostor je ono što nam dopušta da razlikujemo više identičnih simultanih osjeta. On je dakle realitet bez kvaliteta « (Rossi, 1916, 32). Za njega postoji realni prostor bez trajanja i postoji trajanje kod kojega se heterogeni momenti međusobno prožimaju. Kod gibanja se razlikuje dvoje: 1 . prostor u kojem se zbiva gibanje; 2 . akt svijesti pomoću kojega prolazimo taj prostor. Trajanje i gibanje sinteze su duha. Za Bergsona je život i vrijeme realnost. To realno vrijeme zove se trajanje. No, uz to vrijeme postoji i neko pomišljeno vrijeme, a to je prostor, koji još možemo nazivati matematičko vrijeme. On razlikuje numeričku mnogolikost i kvalitativnu mnogolikost. Trajanje je heterogenost momenta koji ulaze jedan u drugi. To povezivanje moguće je zahvaljujući sjećanju.

Rossi zatim obrađuje pitanje slobode volje, koje je, smatra, najvažnije pitanje čitave Bergsonove filozofije. Problem slobode volje u uskoj je vezi s njegovom metafizikom. Taj je problem za njega sofizam, koji se zasniva na pogrešnom razumijevanju organizacije duševnih stanja. Kod determinizma razlikujemo psihički i fizički determinizam. Bergson kritički propituje može li se fizički determinizam svesti na psihički. Psihički determinizam u svoju formu uključuje asocijacionistič- 
ko shvaćanje duha. Za Bergsona je ono djelo potpuno slobodno i zbiljski naše o kojem je odluku donijela cijela duševnost. Postoje dva prigovora determinista indeterministima: 1. promatranje čina kad je već gotov; 2. promatranje čina prije nego će se izvršiti. Bergson smatra da su oba prigovora manjkava. Razlikuju se dva načina kako se mogu shvatiti okolnosti tuđega djelovanja ili kako se duševna stanja neke druge osobe mogu asimilirati našim duševnim stanjima. Prvi način je dinamički, a drugi statički. Dinamički način znači da mi sami doživljavamo sva stanja neke osobe, a statički znači da si stanje neke osobe predočavamo. Bergson zastupa potpunu autonomiju, njegova shvaćanja »slobodnoga djelovanja kao stvaranje nečega novoga nepredvidjenoga iz najdublje nutrine duševnosti približuje shvaćanju umjetničkog stvaranja, jer kao što je djelo umjetnika veće i originalnije što više je u njega postavio svoje najdublje 'ja' tako i svako djelovanje pokazuje to više slobode što više u njega ulažemo svoju cijelu unutrašnjost « (Rossi, 1916, 50).

Bergson je također želio riješiti problem odnosa duše i tijela. Tu se Rossi referira na njegovo djelo Matiere et mémoire ("Materija i pamćenje"). On opreku između duha i tijela svodi na opreku između memorije i percepcije. Čista memorija je duh, a čista percepcija materija. One su same apstrakcije koje dolaze međusobno izmiješane. Bergson smatra da svi problemi pitanja o odnosu duše i tijela dolaze od tuda što se fizičke i psihičke promjene drže duplikatizma. Tomu problemu može se pristupiti s pozicija materijalizma i idealizma, prema kojima se Bergson kritički odnosi. Zatim se postavlja problem sjećanja, koje je prema Bergsonu različito po svojoj prirodi, različito od percepcije. Sjećanje nije rezultat stanja mozga. Rossi navodi kako »ni u kojem slučaju moždjani ne skupljaju uspomene ili slike. Dakle niti u percepciji, niti u sjećanju, niti u višim operacijama duha uopće tijelo ne podnosi direktno do njihove realizacije. Izmedju duše i tijela nalazi se dubok jaz« (Rossi, 1916: 52). Pamćenje pripada području duha, a percepciji pripada materija. Bergson navodi kako nije moguće potpuno suprotstavljanje duha i tijela. Najstrože razlikovanje dovodi do najvećega zbližavanja. Time se dolazi do njegova pojma "slike". Slike su same stvari, one su u našem duhu, one su nam neposredno dane.

\section{2. Četvrti dio disertacije: metafizika}

U uvodnom dijelu Rossi navodi kako Bergson u svojem glavnom djelu L'évolution créatrice želi opravdati svoju metodu. On filozofiji želi dati novu metodu — intuiciju. Intelekt ne može razumjeti pravu bit života. U čovjeku se tako nalazi intelektualna spoznaja i mogućnost intuitivnoga spoznavanja. Intelekt i intuicija mogu shvatiti prirodu i duh.

Bergsonova psihološka istraživanja bila su priprema za njegova metafizička istraživanja. Štoviše, psihološka istraživanja prelaze u metafiziku. On smatra kako nas teorija razvitka organizma može naučiti koji su čimbenici bili prisutni kod razvitka i koji su ga čimbenici uzrokovali. Kod razvitka najvažniji je kontinuitet napredovanja. Intelekt može protumačiti određene pojave u životu, ali on ne može shvatiti totalitet života. Za Bergsona razvitak života trajno je stvaranje 
nečega novoga. Razvitak je života slobodno stvaranje. Bergson zastupa određeni finalizam, s kojim se slaže u tom da je organski život harmonična cjelina. Njegova teleologija tumači prošlost pomoću sadašnjosti. Budućnost je za njega samo proširenje sadašnjosti. Životni je zamah uzrok životnoga ostvarenja i razvijanja. Život tako ima jedinstveni početak, no kad dođe do određenoga stupnja razvitka, dijeli se u dva dijela, a zatim se oni dijele, i tako u nedogled. Bergson smatra da je kretanje kriterij svijesti. Svijest je i uzrok i učinak gibanja. Stoga su biljke nesvjesne jer se ne gibaju. Za njega su životinje određene kretanjem (osjetom i budnom sviješću), a biljke zamrlom sviješću i neosjetljivošću. Životinjski svijet razvio se je u dva smjera. Jedan vodi $\mathrm{k}$ intelektu, a drugi k instinktu. Tako prvi završava u čovjeku, a drugi pak u insektima. Instinkt je po Bergsonu niža forma intelekta. Ni jedan ni drugi stoga se ne mogu definirati. Osnovni je zadatak intelekta pronalaženje oruđa za ovladavanje prirodom. Tako je od prirode čovjek homo faber, a ne homo sapiens. Ljudski intelekt ovisan je o djelovanju, i zbog toga čista spoznaja ne može biti ovisna o njemu. Spoznaja treba obuhvatiti čitavu realnost. Intelekt obuhvaća samo materiju. On je pomogao pri otvaranju govora, koji je nužna pretpostavka društvenoga života. Nadalje, »spoznaja realnosti je dokle samo za svijest u kojoj uz intelekt živi i instinkt. Instinkt je građen prema samome životu, on postupa ogranički prema intelektu« (Rossi, 1916, 91).

Bergson prema postojećim filozofskim sustavima zauzima revolucionarno stajalište. Naime, prema njegovu mišljenju jedino se pomoću intuicionističke metode može doći do pravih rezultata, a ona do sada nije bila priznata kao metoda. U ovom poglavlju Rossi iznosi razlike između antičke, Leibnizove, Spinozine, Kantove i Spencerove filozofije te moderne znanosti.

\subsection{Peti dio disertacije: zaključak}

U zaključku Rossi tvrdi kako Bergson svoju filozofiju određuje kao neovitalizam (Rossi, 1916, 100), što je kontroverzna tvrdnja, s obzirom na to da je sam Bergson bio kritičan prema neovitalizmu, što je vidljivo u njegovu djelu Stvaralačka evolucija. U toj njezinoj tvrdnji očit je utjecaj njezina mentora Alberta Bazale. Rossi navodi kako Bergson u potpunosti prekida s mehanicističkim tumačenjem pojava života. Život je pravi bitak, pa ga ne možemo shvatiti pomoću jednoga načela koje je samo produkt njega samoga. Dio je života i naš psihički život, i prema njemu nam je moguće zamišljati cijeli ostali život. Njegova je najvažnija osobina trajanje, odnosno vrijeme. Život je prevladavanje materije. Najvažniji dio Bergsonove filozofije zasniva se na opreci materije i života. Intuicija je apsolutna spoznaja i možemo ju uzeti u dva smisla: 1. ona znači neposrednu spoznaju; 2. ona je spoznavanje posebnoga, specifičnoga na nekom određenom predmetu. »Intuicija je sasvim individualnog karaktera, pa se stoga često intuicija raznih individua ili istoga individua u razno vrijeme međusobno poriču « (Rossi, 1916, 103). Uz intuitivno spoznavanje, kod Bergsona nalazimo i intelektualno spoznavanje. Područje intuicije je život, a intelektualne spoznaje materija. Intelekt spoznaje kakva je materija uistinu. Na kraju Rossi zaključuje da njegova 
filozofija »već sada počinje podavati novi smjer čitavom filozofskom mišljenju « (Rossi, 1916, 108).

Rossi, sukladno naslovu disertacije, donosi i obrađuje osnovne pojmove Bergsonove filozofije na vrlo čitak i jednostavan način. Pritom smješta njegovu filozofiju unutar postojećih filozofskih sustava. Iz disertacije je vidljivo da Rossi suvereno vlada Bergsonovom filozofijom, kao i poviješću filozofije. Ona se, kada to smatra potrebnim, kritički odnosi prema nekim Bergsonovim stavovima. Važno je napomenuti da Rossi piše disertaciju u vrijeme kada je Bergson živ i u zamahu svojega filozofskoga stvaranja. S obzirom na to da je kasnije objavila članak o njegovoj estetici, jasno je da je i poslije disertacije pratila razvoj njegove filozofske misli. Kao što je prije napomenuto, djelovanje Ivane Rossi bilo je usmjereno prema problemu percepcije i estetike. Ona je u svojim psihološkim istraživanjima, zajedno s Elzom Kučera, svela na zajednički nazivnik problem percepcije lijepoga. Teme koje su obrađene iz Bergsonove filozofije dobrim dijelom ukazuju na njezina buduća djelovanja, ako ih već u potpunosti ne određuju.

\section{Recepcija filozofije Henri Bergsona u Hrvatskoj}

»Teško je razmišljati o drugom filozofu koji je bio toliko široko rasprostranjen, proslavljen i utjecajan u svoje vrijeme kao Henri Bergson« (Sinclair, 2020, 1). Još za vrijeme života Henrija Bergsona, ${ }^{7}$ o njemu se je pisalo i objavljivalo u Hrvatskoj. Albert Bazala dvaput je objavio enciklopedijske natuknice o Henriju Bergonu. Prva je natuknica objavljena u Bazalinoj Povijesti filozofije (Bazala, 1912, 276-279), a druga 1941. godine u Hrvatskoj enciklopediji. Ivana Rossi obranila je svoju disertaciju 1916. godine, dakle sedam godina od objavljivanja Bergsonova najvažnijega djela L'évolution créatrice. Ona je 1929. godine u časopisu Književnik objavila kratak tekst naslovljen Nekoliko misli Henri Bergsona o estetici (Rossi, 1929). Godine 1924. franjevac i filozof Boniface Badrov (1896.1974.) na Sveučilištu u Fribourgu obranio je disertaciju La notion de la vie d'apres Bergson ("Bergsonov pojam života"), koja je uskoro i objavljena (Badrov, 1926). Zatim je svećenik Đuro Gračanin (1899.-1973.) na Bogoslovnom fakultetu u Zagrebu 1935. godine napisao disertaciju o Bergsonu Moderni filozof - branitelj kršćanstva?, objavljena iste godine (Gračanin, 1935). O toj disertaciji prikaz je napisao Stjepan Zimmermann (1884.-1963.) (Zimmermann, 1935). Dugogodišnja profesorica na Filozofskom fakultetu u Zadru Marija Brida (1912.-1993.) u svojoj disertaciji Život - doživljaj, koju je obranila 1937. na Filozofskom fakultetu u Zagrebu, u poglavlju Neodređenost teze život obrađuje Bergsonovu filozofiju

7 Henri Bergson (1859.-1941.) francuski je filozof. Bio je profesor na Collège de France. Godine 1927. dobio je Nobelovu nagradu za književnost. Tvorac je filozofije života, a njegovo djelo dio je intelektualnoga pokreta koji se je javio na prelazu iz 19. u 20. stoljeće. Glavna djela su mu: Essai sur les données immédiates de la conscience ("Ogled o izravnim činjenicama svijesti", 1899.), L'évolution créatrice ("Stvaralačka evolucija", 1907.), L'énergie spirituelle ("Duhovna energija", 1919.), Durée et simultanéité ("Trajanje i istodobnost", 1922.), Les deux sources de la morale et de la religion ("Dva izvora morala i religije", 1932.), Mémoire et vie ("Pamćenje i život", 1957.). 
(Brida, 1937, 5-19). Povodom smrti Henrija Bergsona Gračanin je napisao tekst Osvrt na Bergsona (Gračanin, 1941).

Nakon Drugoga svjetskoga rata, Kruno Krstić (1905.-1987.) napisao je 1958. enciklopedijsku natuknicu za Enciklopediju likovnih umjetnosti. Vladimir Filipović u djelu Novija filozofija Zapada posvetio je jedno cijelo poglavlje Bergsonu pod naslovom Henri Bergson. U istoj knjizi donesen je prijevod Bergsonova teksta Uvod u metafiziku (Filipović, 1968, 95-100). Godine 1993. u svojoj Povijesti filozofije Branko Bošnjak (1923.-1996.) u trećem svesku posvetio je čitavo jedno poglavlje Bergsonovoj filozofiji pod naslovom Filozofija evolucije: Henri Bergson « (Bošnjak, 1993, 389-397). Bergson se kratko spominje i u Hrvatskom općem leksikonu iz 1996. godine. Natuknica o Bergsnonu nalazi se i u Hrvatskoj enciklopediji iz 2000. godine. U Filozofskom leksikonu Željko Pavić napisao je natuknicu Bergson, Henri (Pavić, 2012).

Što se tiče recentnijih tekstova o Bergsonu, valja spomenuti da je godine 2013. Ksenija Premur objavila knjigu Bergson i Buddha. Riječ je o doktorskoj disertaciji iz 1998. godine, koja je obranjena pod naslovom Dinamička struktura svijesti u poredbenoj analizi Bergsonove filozofije i ranog buddhističkog nauka na osnovi komparativno-filozofskog nacrta Čedomila Veljačića. Dobra poznavateljica filozofije Marije Bride, Iris Tićac u knjizi Marija Brida: Filozofkinja slobode jedno je poglavlje posvetila Bridinoj recepciji Bergsonove vizije bistvovanja (Tićac, 2012, 81-117). Tićac je još u časopisu Filozofska istraživanja objavila članak Marija Brida i Roman Ingarden: Dva fenomenološka “čitanja” Bergsonove koncepcije intuicije (Tićac, 2019). O Bridinu razumijevanju Bergsonove filozofije pisala je i Heda Festini (1928.-2018.) u tekstu Marija Brida (1912.-1993.) o H. Bergsonu (Boršić i Skuhala Karasman, 2017). U Prilozima za istraživanje hrvatske filozofske baštine objavljen je članak Zlatka Posavca (1931.-2019.) Estetika — posebno područje interesa dr. Krune Krstića, u kojem autor tematizira i Bergsonov utjecaj na Krstića (Posavac, 2019).

Što se prijevoda Bergsonovih djela na hrvatski jezik tiče, prevedeno je sljedeće: Bosiljka Brlečić prevela je na hrvatski jezik njegovo djelo Smijeh: Esej o značenju komičnoga (Bergson, 1987). Zatim je Dinko Štambak preveo Henrija Bergsona, koji je s drugim filozofima našao mjesto u knjizi Odabrana francuska proza (Štambak, 1998). Tomislav Medak preveo je djelo Stvaralačka evolucija (Bergson, 1999), a Sanja Grahek prevela je djelo Ogled o neposrednim datostima svijesti (Bergson, 2000). Zadnji je prijevod Dragutina Slada Bergsonove knjige Vrijeme i sloboda volje (Bergson, 2011).

Svakako je zanimljivo da su u Zagrebu obranjene tri disertacije koje se bave Bergsonom u vremenu kada je on još bio živ. To znači da je već tada njegova misao imala veliki utjecaj, kako u filozofiji tako i u književnosti u Hrvatskoj (Posavac, 2019, 525). S druge strane, nemoguće je ne primijetiti kako u Hrvatskoj nema mnogo objavljenih tekstova o Henriju Bergsonu. Njegovo se ime pretežno provlači kroz knjige koje se bave estetikom 20. stoljeća, no jedva išta više od toga. Isto tako treba spomenuti kako neka od najvažnijih Bergsonovih djela nisu nikad prevedena na hrvatski jezik. 
Sama disertacija Ivane Rossi nije imala nikakvu recepciju u našim filozofskim krugovima. Nisam pronašla ni jedan tekst koji bi barem spomenuo njezin doktorski rad. Tomu u prilog ide i činjenica da je njezina disertacija pohranjena u knjižnici Filozofskoga fakulteta u Zagrebu i da nikad nije bila objavljena, te je stoga još i danas teško dostupna čitateljima.

Na kraju treba spomenuti da je Henri Bergson danas iznimno popularan filozof. Već nam površni pregledi internetskih baza podataka svjedoči o mnoštvu radova o tom filozofu. Njegovo se ime spominje u preko 5.000 članaka, 3.000 disertacija, 100 knjiga i dr. objavljenih u posljednjih dvadesetak godina. Najčešće su teme njegovo razumijevanje instinkta i memorije. Ovdje treba spomenuti najnoviju monografiju o Bergsonu. Mark Sinclair autor je knjige naslovljene Bergson. Bavi se svim relevantnim temama Bergsonove filozofije donoseći i opširnu biografiju i bibliografiju. Godine 2015. na engleski jezik prevedena je i objavljena jedna od najvažnijih knjiga o Bergsonu njegova učenika Vladimira Jankélévitcha (1903.-1985.) Henri Bergson koja je prvi puta objavljena na francuskom jeziku 1931. godine. Knjiga je bila revidirana 1959. godine kako bi se u nju uključili i kasniji Bergsonovi radovi. Godine 2013. objavljena je knjiga Alaxandrea Lefebvrea o Bergsonovoj političkoj filozofiji Human Rights as a Way of Life. Dakle, produkcija tekstova o Bergsonu izvan Hrvatske bogata je i bavi se različitim sferama njegove filozofije.

\section{Zaključak}

Iako Ivana Rossi nije bila plodna filozofkinja, za svojega života objavila je jedan članak i prijevod djela Jamesa Barrieja Peter Pan u perivoju Kensington. Ipak je ostavila trag na pedagoški, kulturni i filozofski život na našim prostorima. Prije svega jedna je od prvih žena uopće koje su doktorirale na Filozofskom fakultetu u Zagrebu, a prva koja je na toj ustanovi doktorirala filozofiju. Njezina teza bila je posvećena tada vrlo aktualnoj filozofiji Henrija Bergsona. Rossi je svojom disertacijom zasigurno pridonijela afirmaciji Bergsonove filozofije u nas. No, na žalost ta disertacija nikada nije bila objavljena. Čitavu svoju karijeru posvetila je obrazovanju mladih naraštaja radeći kao gimnazijska profesorica u Zagrebu. Surađivala je i u psihološkim istraživanjima s još u nas nedovoljno poznatom filozofkinjom, bibliotekarkom i psihologinjom Elzom Kučera. U nas se do danas nije provodilo sustavno istraživanje Bergsonove filozofske misli. Sporadično se javljaju članci, poglavlja u knjigama ili najčešce enciklopedijske natuknice o njegovoj filozofiji. Kad se pogleda pisani opus i djelovanje Rossi, izgleda da ona nije puno napravila u svojoj karijeri, pogotovo kada se usporedi s muškim kolegama koji su djelovali u to vrijeme, no njezino se djelovanje treba promatrati u kontekstu tada još uvijek prilično patrijarhalnoga obrazovnoga i akademskoga sustava. Njezino djelovanje i jedan objavljeni tekst imaju daleko veću važnost nego što se čini na prvi pogled jer se nalaze na početku ženske emancipacije u akademskim krugovima i ukazuju na činjenicu da i žene mogu biti ravnopravne na tom području. 


\section{Literatura}

Badrov, Boniface (1926). La notion de la vie d'apres Bergson. Sarajevo: Štamparski zavod. Ballard, Edward (1960). The Philosophy of Jules Lachelier. The Hague: Springer.

Barrie, James (1922). Petar Pan u perivoju Kensington. Zagreb: Udruženje za unapređivanje dječje književnosti.

Bazala, Albert (1912). Povijest filozofije. Zagreb: Matica hrvatska.

Bergson, Henri (1987). Smijeh: Esej o značenju komičnoga. Zagreb: Znanje.

Bergson, Henri (1999). Stvaralačka evolucija. Zaprešić: Igitur.

Bergson, Henri (2000). Ogled o neposrednim datostima svijesti. Zagreb: Demetra.

Bergson, Henri (2011). Vrijeme i sloboda volje. Zagreb: Feniks knjiga.

Boršić, Luka, Skuhala Karasman, Ivana (ur.) (2017). Hrvatske filozofkinje. Zagreb: Institut za filozofiju, 177-184.

Bošnjak, Branko (1993). Povijest filozofije. Zagreb: Matica hrvatska.

Boutroux, Émile (1908). La philosophie en France depuis 1867. Revue de métaphysique et de morale, 16(6), 683-716.

Brida, Marija (1937). Život — doživijaj. Zagreb: Tiskara Merkantile.

Filipović, Ljiljana (2016). Klub krivaca. Zagreb: Izdanja Antibarbarus.

Filipović, Vladimir (1968). Novija filozofija Zapada. Zagreb: Matica hrvatska.

Gračanin, Đuro (1935). Moderni filozof — branitelj kršćanstva? Sarajevo: Nova tiskara.

Gračanin, Đuro (1941). Osvrt na Bergsona. Bogoslovska smotra, 24(2), 163-166.

Kučera, Elza (1938). O životu i radu Camille Lucerne. Zagreb: Zaklada tiskare Narodnih novina.

Luetić, Tihana (2001). Prve studentice Zagrebačkog sveučilišta. Hrvatska revija, 1(3-4), $1-14$.

Luetić, Tihana (2002). Prve studentice Mudroslovnog fakulteta kr. Sveučilišta Franje Josipa I. u Zagrebu. Povijesni prilozi, 21(22), 167-207.

Marčeta, Željka (2011). Gimnazija maršala Tita u Zagrebu 1945.-1948. (Diplomski rad). Filozofski fakultet Sveučilišta u Zagrebu.

Ograjšek Gorenjak, Ida (2006). Otvaranje ženskog liceja u Zagrebu. Povijest u nastavi, $4(8), 147-176$.

Pavić, Željko (2012). Bergson, Henri. U: Filozofski leksikon (str. 106-107). Zagreb: Leksikografski zavod Miroslava Krleže.

Posavac, Zlatko (2019). Estetika - posebno područje interesa dr. Krunoslava Krstića. Prilozi za istraživanje hrvatske filozofske baštine, 45(2), 517-557.

Rossi, Ivana (1916). Osnove filozofske misli Henri Bergsona (Doktorski rad). Filozofski fakultet Sveučilišta u Zagrebu.

Rossi, Ivana (1929). Nekoliko misli Henri Bergsona o estetici. Književnik, 2, 67-68.

Sinclair, Mark (2020). Bergson. Abingdon: Routledge.

Štambak, Dinko (1998). Odabrana francuska proza. Zagreb: Matica hrvatska.

Tićac, Iris (2012). Marija Brida: Filozofkinja slobode. Split: Naklada Bošković.

Tićac, Iris (2019). Marija Brida i Roman Ingarden: Dva fenomenološka "čitanja” Bergsonove koncepcije intuicije. Filozofska istraživanja 39(2), 313-333.

Zimmermann, Stjepan (1935). Dr. Gjuro Gračanin, Moderni filozof-branitelj kršćanstva? Bogoslovska smotra, 23(4), 452-455. 
Arhivsko gradivo

Arhiv grada Zagreba

HR-DAZG-108. Gimnazija maršala Tita u Zagrebu.

HR-DAZG-111. III. muška realna gimnazija u Zagrebu.

HR-DAZG-114. I. ženska realna gimnazija u Zagrebu.

Nacionalna i sveučilišna knjižnica u Zagrebu

HR-NSK-R 4771b. Ostavština Elze Kučere. Pisma drugih njojzi.

The Croatian Woman Philosopher Ivana Rossi on the Philosophy of Henry Bergson

Ivana Skuhala Karasman*

\section{Summary}

The Croatian woman philosopher Ivana Rossi (1892-1963) was the first Croatian woman to defend a doctorate in philosophy in 1916 at the Faculty of Philosophy in Zagreb. The topic of her dissertation was „The Basic Thoughts of Henry Bergson's Philosophy" (Osnovne misli filozofije Henri Bergsona). This dissertation was written much before Henri Bergson's death in 1941, while he was professionally still very active. Ivana Rossi's dissertation is the first serious presentation of Henri Bergson's philosophical thought among the South Slavs. For hitherto unknown reasons - mostly likely personal - Ivana Rossi did not even attempt to work as a professional philosopher in the Academia. (She spent her entire professional career as a high school teacher in Zagreb, working in three different gymnasia: the "Kraljevska ženska realna gimnazija", the "Partizanska realna gimnazija", and the "III. muška realna gimnazija”.) In 1929, she published the article, „Some of Henri Bergson's Thoughts on Aesthetics “in the journal Književnik. Her second published work is her translation of James Barrie's „Peter Pan in Kensington Park“ published in 1922. This book is the first Croatian translation of a book on Peter Pan. In this article, in addition to the hitherto little-known biography of Ivana Rossi and the reception of Bergson's philosophy in Croatia, the author also presents a summary of her dissertation.

Key words: Ivana Rossi; Henri Bergson; woman philosopher; dissertation; reception of Bergson's philosophy; psychology; metaphysics

* Ivana Skuhala Karasman, Ph.D., Senior Research Associate, Institute of Philosophy. Address: Ulica grada Vukovara 54, 10000 Zagreb, Croatia. E-mail: ivana@ifzg.hr

This text was written as a part of the project "Croatian Women Philosophers in the European Context" financed by the Croatian Science Foundation under the number HRZZ UIP-2017-05-176 